\title{
PENGEMBANGAN KAPABILITAS KOLABORASI DINAMIS UNTUK MENINGKATKAN KINERJA BISNIS KOPERASI JASA KEUANGAN SYARIAH DI JAWA TENGAH
}

\author{
Faqih Nabhan \\ Dosen Sekolab Tinggi Agama Islam Negeri (STAIN) Salatiga \\ faqibnabban@yaboo.co.id
}

\begin{abstract}
Since the last two decades, there has been controversy over the influence of collaborative partnerships on the performance of the organization. At the practical level, the low number of mudaraba and musharaka practices in the financing on Islamic financial institutions shows the significancy of conceptual frameworks in developing organizational capability in conducting collaborative partnerships that can improve the performance of Islamic financial institutions. Through indepth theoretical and empirical study, it can be presented a conceptual model of the dynamic collaboration capabilities to enhance the business performance of Islamic financial institutions. The population was Islamic Financial Services Cooperatives in Central Java with 151 respondents spread over several districts and cities in Central Java. The study used purposive sampling and Structural Equation Model (SEM) to analyze the data.
\end{abstract}

Keywords: Dynamic Collaboration Capabilities, Business Performance, and Islamic Cooperatives.

\begin{abstract}
Abstrak
Sejak dua dekade yang lalu terdapat kontroversi pengarub kolaborasi kemitraan terhadap kinerja organisasi. Pada tataran praktis rendabnya praktik mudharabah dan musyarakab dalam penyaluran dana oleb lembaga keuangan syariah, menunjukkan pentingnya kajian simpul-simpul konseptual mengembangkan kapabilitas organisasi dalam melakukan kolaborasi kemitraan yang dapat meningkatkan kinerja lembaga keuangan syariab. Melalui telaah teoritis mendalam dan temuan penelitian empiris disajikan sebuab model konseptual mengenai kapabilitas kolaborasi dinamis, sebingga mampu meningkatkan kinerja bisnis lembaga keuangan syariah. Populasi dalam penelitian ini adalah Koperasi Jasa Keuangan Syariah (KJKS) di Jawa Tengah dengan sampel 151 responden yang tersebar di beberapa kabupaten dan kota di Jawa Tengah. Teknik sampling yang digunakan adalab purposive sampling, kemudian dianalisis dengan menggunakan Structural Equation Model (SEM).
\end{abstract}

Kata kunci: Kapabilitas Kolaborasi Dinamis, Kinerja Bisnis, dan Koperasi Syariah. 


\section{Pendahuluan}

Kolaborasi antar organisasi menjadi kebijakan yang strategis untuk mendapatkan akses sumberdaya, kapabilitas, ketrampilan dan pengetahuan yang berasal dari luar perusahaan. Perusahaan mencari berbagai hasil operasional dan keuangan dari kegiatan kolaborasi. Simonim (1997:150) menyatakan bahwa strategi kolaborasi antar organisasi membutuhkan kapabilitas kolaborasi. Hal ini dibangun perusahaan dalam rangka menumbuhkan sumberdaya yang unggul untuk berhasil mencapai tujuan kolaborasi. Kolaborasi yang efektif dapat meningkatkan efisiensi operasi, efektifitas organisasi dan kinerja.

Erlena, Cerasi dan Daltung (2005) menyatakan bahwa kolaborasi lembaga keuangan memungkinkan efisiensi mendapatkan informasi melalui sharing informasi sehingga meningkatkan kualitas piutang dan kinerja keseluruhan perusahaan. Ann dan Steve (2006: 1176) menemukan bahwa kolaborasi dengan pertukaran informasi berpengaruh signifikan terhadap peningkatan kinerja. Hal ini diperoleh melalui efisiensi biaya, fleksibilitas, kualitas layanan dan pengadaan produk. Ken dan Nigel (2007: 207) menemukan bahwa semakin tinggi kolaborasi akan meningkatkan keuntungan organisasi melalui peningkatan kinerja.

Beberapa peneliti menemukan bahwa kolaborasi tidak selamanya mampu meningkatkan kinerja. Diamond (1984:393) menyatakan bahwa kolaborasi justru akan menurunkan kinerja karena pengawasan menjadi tidak efisien. Haris dan Raviv (1979:250) menemukan bahwa pengawasan yang dilakukan dengan beberapa lembaga keuangan memunculkan biaya yang lebih tinggi dibanding dengan yang dilakukan oleh lembaga keuangan secara individual. Hal ini terjadi karena adanya tumpang tindih pengawasan antara lembaga keuangan pertama dengan lembaga keuangan kedua.

Bolton dan Scharfstein (1996:20) menyatakan bahwa biaya pengawasan terhadap satu debitur yang dilakukan oleh beberapa bank akan mengakibatkan duplikasi pengawasan yang tidak efisien, dan renegosiasi hutang akan lebih kompleks apabila lebih banyak bank yang terlibat. Petersen dan Rajan (1994:30) menyatakan bahwa kolaborasi perbankan dalam penyaluran dana mengakibatkan 
peningkatan biaya pengawasan oleh bank dan debitur harus menanggung biaya bunga bank yang lebih tinggi akibat tidak efisiensinya penyaluran kredit oleh bank.

Carleti et.al., (2005) menemukan bahwa kolaborasi lembaga keuangan meningkatkan daya jangkau layanan nasabah sehingga meningkatkan kualitas layanan dan daya saing dalam mendapatkan nasabah. Keuntungan yang diperoleh dari hubungan kerjasama antar lembaga keuangan ini akan meningkatkan kinerja secara keseluruhan. Lembaga keuangan mampu melayani nasabah yang berada diwilayah yang tidak dapat dijangkau oleh jaringannya sendiri.

Kolaborasi dengan lembaga keuangan lain memungkinkan untuk melakukan lebih banyak diversifikasi dalam alokasi penyaluran dana. Chiesa (2001:20) menemukan bahwa kolaborasi lembaga keuangan memungkinkan lembaga keuangan untuk meningkatkan kemampuan diversifikasi dan daya saing. Terdapat penelitian yang menunjukkan bahwa kolaborasi tidak selamanya berhasil. Zineldin dan Dodourova (2005:460), menyatakan bahwa tingkat kegagalan dari kolaborasi dalam bentuk aliansi mencapai 70 persen. Park dan Ungson (2001: 37), menyatakan bahwa lima puluh persen dari strategi aliansi mengalami kegagalan. Lebih lanjut Palakshappa dan Gordon (2007: 264) menemukan dalam penelitiannya bahwa perusahaan tidak mampu merealisasikan keuntungan dari kegiatan kolaborasi. Perusahaan yang melakukan kolaborasi juga tidak mampu mendapatkan ketrampilan dan kompetensi baru dari kegiatan kolaborasi. Tingginya tingkat kegagalan kolaborasi yang dilakukan dalam bentuk aliansi menimbulkan pertanyaan untuk diteliti lebih lanjut.

Keadaan Koperasi Jasa Keuangan Syariah (KJKS) di Jawa Tengah diketahui KJKS di Jawa Tengah ini memiliki asset yang cukup besar yaitu lebih dari Rp2 triliun dan mampu mencatatkan keuntungan SHU sebesar Rp134,6 milyar. KJKS di Jawa Tengah juga mampu menyerap tenaga kerja sedikitnya 5.000 orang. Beberapa indikator ini menunjukkan besarnya kontribusi KJKS bagi perekonomian daerah terutama di Jawa Tengah. Namun demikian dari 639 KJKS di Jawa Tengah yang termasuk sebagai koperasi berkategori sehat tidak mencapai 20\%. Soetriono (2004, 
2) mengemukakan bahwa saat ini koperasi secara umum sedang menghadapi permasalahan kurangnya kemitraan usaha yang saling menguntungkan. Melihat keadaan KJKS di Jawa Tengah seperti ini maka perlu untuk terus-menerus didukung salah satunya dengan cara penelitian untuk semakin memperkuat pengembangan bisnis koperasi syariah di Jawa Tengah.

\section{Kapabilitas Kolaborasi Dinamis}

Kapabilitas dinamis adalah kemampuan perusahaan untuk mengubah dan menyesuaikan basis sumberdayanya (seperti mendapatkan dan menyebarkan sumberdaya, mengintegrasikan dan mengkombinasikan) untuk mendapatkan penciptaan nilai baru yang strategis, yang diperoleh dari rutinitas organisasi dan rutinitas strategis (Grant, 1996). Dengan kata lain, kapabilitas dinamis adalah pendorong terhadap kegiatan penciptaan, evolusi dan rekombinasi sumberdaya menjadi sumberdaya baru sebagai keunggulan bersaing (Teece et al., 1997). Eisenhardt (1989) menyatakan bahwa kapabilitas kolaborasi adalah kemampuan perusahaan dalam menggunakan sumberdaya, dalam hal ini proses untuk mengintegrasikan, menyusun kembali (reconfigure), memperoleh dan melepaskan sumberdaya, untuk menyesuaikan dengan perubahan pasar dan bahkan menciptakan perubahan pasar. Kapabilitas dinamis adalah rutinitas organisasional dan rutinitas strategis yang memungkinkan bagi perusahaan untuk mencapai penyusunan sumberdaya baru. Hampir sama dengan definisi di atas Kogut dan Zander (1992) menyatakan tentang kapabilitas kombinatif yaitu proses organisasional sehingga memungkinkan bagi perusahaan untuk mengumpulkan dan memperoleh sumberdaya pengetahuan, dan menghasilkan aplikasi baru dari sumberdaya tersebut.

Kapabilitas dinamis dapat berupa kapabilias untuk melakukan integrasi sumberdaya. Misalnya rutinitas pengembangan produk yang memungkinkan bagi manajer mengkombinasikan ketrampilan yang bervariasi dan latar belakang fungsional untuk menciptakan produk dan jasa yang bernilai (Helfat dan Raubitschek, 2000). Kapabilitas dinamis dapat berupa kapabilitas pengambilan keputusan strategis yang memungkinkan bagi manajemen untuk 
menyatukan berbagai macam unit bisnis, bagian-bagian, dan karyawannya (Judge dan Miller, 1991).

Berdasarkan telaah literatur di atas dapat diajukan proposisi sebagai berikut:

Proposisi : (Proposisi Kapabilitas Kolaborasi Dinamis)

"Kapabilitas kolaborasi dinamis adalah kemampuan mengintegrasikan keunggulan sumberdaya anggota kolaborasi sehingga mampu beradaptasi terhadap perubahan lingkungan. Kapabilitas kolaborasi dinamis seperti ini berpotensi menentukan kinerja kolaborasi".

Proposisi di atas dapat disajikan dalam gambar sebagai berikut:

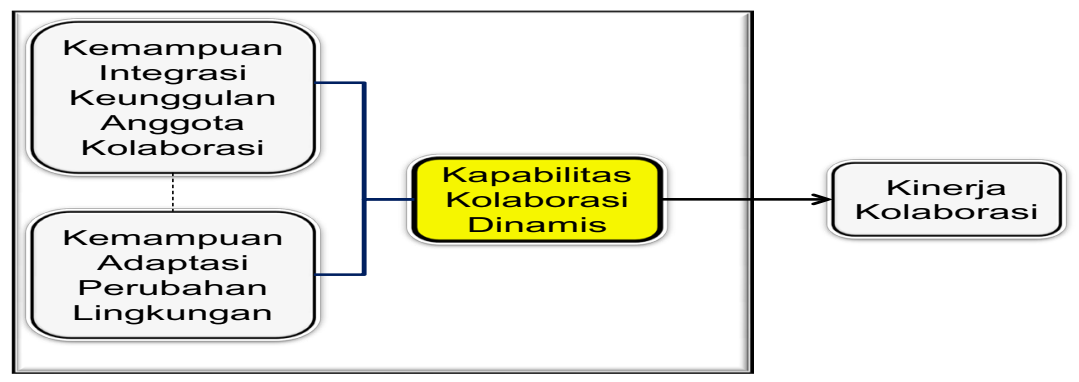

Sumber; Dikembangkan untuk penelitian ini Gambar 1

\section{Proposisi Kapabilitas Kolaborasi Dinamis (KKD)}

Menurut Kandemir et al., (2006:330) orientasi kolaborasi adalah kompetensi yang terdiri dari tiga kemampuan yaitu scanning, coordinating dan learning. Johnson et al., (2003:80) juga menyatakan bahwa orientasi pada pasar menghasilkan kecenderungan untuk fokus pada konsumen dengan mengidentifikasi, menganalisa, memahami dan menjawab kebutuhan pasar. Mengacu pada Johnson et al., (2003), maka fleksibilitas dalam konteks kolaborasi dipengaruhi oleh orientasi pada kolaborasi, yaitu sejauh mana kecenderungan perusahaan dalam melakukan kolaborasi. Oleh karena itu, diajukan hipotesis sebagai berikut. 
Hipotesis 1: Semakin tinggi derajat orientasi pada relasi kolaborasi, maka semakin tinggi fleksibilitas organisasi dalam mengelola kolaborasi sumberdaya unggul anggota kolaborasi.

Harapan keberlanjutan kolaborasi mampu meningkatkan fleksibiitas dalam relasi kolaborasi (Johnson, 1999:8). Anggota kolaborasi yang melihat relasi kolaborasi sebagai kegiatan jangka panjang maka akan cenderung bersikap akomodatif terhadap perubahan keinginan partner kolaborasi. Anggota kolaborasi yang memiliki harapan keberlanjutan kolaborasi cenderung mampu menyesuaikan diri pada kondisi dan perubahan. Selanjutnya anggota kolaborasi akan menunjukkan fleksibitasnya dalam berkolaborasi karena mereka akan difahami sebagai perusahaan yang mampu mengakomodasi kepentingan-kepentingan anggota kolaborasi. Anggota kolaborasi yang mengharapkan kolaborasi dapat berjalan berkelanjutan maka mereka akan memberikan kelonggaran dalam menyelesaikan masalah yang timbul selama proses kolaborasi. Oleh karena itu, diajukan hipotesis sebagai berikut.

Hipotesis 2: Semakin besar harapan anggota kolaborasi untuk melakukan relasi kolaborasi secara berkelanjutan, maka semakin meningkat fleksibilitas manajerial perusahaan dalam mengelola kolaborasi sumberdaya unggul anggota kolaborasi.

Lin dan Kuo (2007) menemukan bahwa pembelajaran organisasi mampu meningkatkan kapabilitas managerial. Derajad pembelajaran memberikan dampak yang signifikan terhadap kemampuan integrasi dan kapabilitas mengelola sumberdaya. Dampak pembelajaran juga mempengaruhi reaksi konsumen, karyawan dan partner perusahaan pada perusahaan. Reaksi ini akan baik apabila organisasi memiliki potensi dalam menghasilkan dan mengaplikasikan pengetahuan yang mampu memandu memenuhi harapan pihak lain sepanjang sesuai dengan tujuan perusahaan.

Perusahaan yang memiliki kapabilitas pembelajaran yang baik mampu mengkoordinasikan dan mengkombinasikan 
sumberdaya dan kapabilitas dengan cara-cara yang baru dan unik (Teece et al., 1997). Selanjutnya Prieto dan Revilla (2006), menemukan bahwa kapabilitas pembelajaran melibatkan aliran pengetahuan (learning flow) yang terdiri dari eksplorasi dan eksploitasi pengetahuan sehingga memungkinkan bagi peningkatan pengetahuan dan ketrampilan ditingkat individual, kelompok dan organisasi. Knowledge stocks yang dimiliki perusahaan membentuk kapabilitas bagi perusahaan yang sangat berarti mencapai tujuan perusahaan. Lebih lanjut Richey dan Autry (2009) menemukan bahwa organizational learning capability dalam meningkatkan kualitas kolaborasi antar perusahaan (interfirm collaboration). Oleh karena itu dapat diajukan hipotesis sebagai berikut:

Hipotesis 3: Semakin baik kapabilitas pembelajaran kolaborasi perusahaan, maka semakin meningkat kapabilitas integrasi sumberdaya anggota kolaborasi.

Pengalaman menjadi variabel yang utama untuk pengembangan kapabilitas (Teece et al., 1997). Tanpa adanya pengalaman dapat menjadi penyebab kegagalan aliansi. Perusahaan yang mampu memanfaatkan pengalaman memungkinkan menjadi lebih efektif dalam mengelola proses dan kegiatan tertentu dibanding perusahaan yang kurang berpengalaman (Das dan Teng, 2002).

Gulati (1999:400) menunjukkan bahwa faktor utama yang mempengaruhi cara perusahaan mengelola kolaborasi adalah pengalaman kolaborasi sebelumnya. Pengalaman kolaborasi memungkinkan perusahaan untuk menilai mekanisme dan kegiatan yang efektif untuk mengelola sumberdaya bahkan pada kegiatan yang kompleks. Pengalaman juga dapat memberikan kemampuan bagi perusahaan untuk melakukan pengembangan rutinitas dan mekanisme organisasi dalam rangka memfasilitasi koordinasi antar organisasi dan untuk memilih mitra koalisi yang tepat di masa depan (Heimeriks dan Duysters, 2007).

Lebih lanjut Oliver (2010) menemukan bahwa pengalaman aliansi mampu meningkatkan kapabilitas aliansi perusahaan. Heimeriks dan Duysters (2007) juga menyatakan bahwa semakin banyak pengalaman maka semakin meningkatkan kapabilitas aliansi 
perusahaan. Berdasarkan konsep-konsep pemikiran Oliver (2010) dan Heimeriks dan Duysters (2007) maka dapat diajukan kesimpulan bahwa pengalaman kolaborasi akan membantu perusahaan dalam mengembangkan manajemen integrasi sumberdaya kolaborasi. Sehingga perusahaan yang berpengalaman dengan kolaborasi cenderung lebih mampu mengelola kemitraan masa depan yang lebih efektif. Berdasarkan telaah di atas maka dapat diajukan hipotesis sebagai berikut:

Hipotesis 4: Semakin tinggi pengalaman perusahaan dalam berkolaborasi, maka semakin tinggi kapabilitas perusahaan dalam mengintegrasikan sumberdaya anggota kolaborasi.

Fleksibilitas organisasional adalah kemampuan untuk menyesuaikan operasional dan kebijakan secara cepat dalam merespon perubahan lingkungan. Berdasarkan teori organisasi khususnya teori kefektifan organisasi, pada open system model fleksibilitas organisasi diperlukan dalam mencapai tujuan organisasi (Robbins, 1994). Fleksibilitas mutlak diperlukan dalam membina suatu kolaborasi, fleksibilitas akan merespon setiap perubahan yang terjadi dengan kemampuan beradaptasi dalam upaya peningkatan keberhasilan integrasi strategi antar perusahaan (Johnson, 1999:12).

Dalam konsep syirkah (kerjasama dengan pola syariah) memiliki prinsip pembagian keuntungan dan kerugian (Shingeri, 1994), serta mendahulukan musyawarah Dimyati (1989). Kesamaan prinsip syariah mendukung kemampuan anggota kolaborasi dalam menyesuaikan diri (Islahi, 1988). Kesadaran bahwa syirkah memiliki konsekuensi untung dan rugi, memberikan dorongan bagi anggota kolaborasi untuk memiliki ruang yang cukup untuk bersikap fleksibel dalam menerima kondisi yang tidak diinginkan selama melakukan kolaborasi.

Sejalan dengan pemikiran Teece et al. (1997) bahwa fleksibilitas organisasional sebagai kombinasi kemampuan manajerial dan organisasional yang mendorong organisasi untuk mampu melakukan penyesuaian secara cepat menghadapi perubahan lingkungan. Bello dan Gilliland (1997:28) dalam penelitiannya 
menemukan bahwa fleksibilitas yang dimiliki para pelaku kerjasama bilateral mampu meningkatkan efektifitas dan efisiensi kinerja kerjasama. Fawcett et al., (1996: 187) menemukan bahwa kompetensi flexibilitas memungkinkan perusahaan bisa melakukan sesuatu dengan cepat dan responsive terhadap pasar, sehingga flexibilitas berpengaruh positif terhadap kinerja. Ginn (2006:118) menemukan bahwa fleksibilitas berpengaruh positif terhadap efektifitas perusahaan. Oleh karena itu dapat diajukan hipotesa sebagai berikut:

Hipotesis 5: Semakin tinggi fleksibilitas organisasi, maka semakin besar efektifitas organisasi dalam kegiatan kolaborasi.

Berdasarkan teori interfirm collaboration, kolaborasi dibangun melalui proses negosiasi, komitmen, implementasi dan penilaian (Van de Ven, 1976). Kapabilitas integrasi mampu membantu mendorong potensi inovasi dan meningkatkan kecenderungan menciptakan inovasi produk dan jasa serta inovasi proses dengan cara pembelajaran dan mencari pengetahuan dan kapabilitas baru (Liao et al., 2009:271). Kapabilitas integrasi sumberdaya yang dimiliki perusahaan tidak hanya dapat dimiliki oleh salah satu departemen tetapi bisa menyebar diseluruh aktivitas perusahaan. Oleh karena itu perusahaan perlu mencari dan meningkatkan kapabilitas integrasi sumber daya secara terus menerus dan luas (Hambricks, 1982).

Semakin besar kapabilitas integrasi sumberdaya perusahaan maka semakin baik kemampuan perusahaan untuk berinovasi (Liao et al., 2009:271). Kapabilitas integrasi mampu meningkatkan inovasi karena perusahaan mampu menyebarkan dan memanfaatkan sumberdaya yang tersedia. Kapabilitas integrasi meningkatkan kemampuan perusahaan yang berkolaborasi mampu mengeksploitasi dan memobilisasi sumberdaya dalam mencipatakan produk dan layanan baru. Menurut Lok et al. (2008) kualitas kapabilitas integrasi menentukan derajat inovasi perusahaan. Hal ini terjadi karena kapabilitas integrasi merupakan bagian dari konstruk modal sosial yang mendorong transfer pengetahuan dari organisasi (Lok et al., 2008). 
Berdasarkan konsep-konsep pemikiran Liao et al. (2009) dan Lok et al. (2008) maka dapat disimpulkan bahwa kapabilitas integrasi sumberdaya anggota kolaborasi mampu meningkatkan inovasi produk dan layanan perusahaan. Oleh karena itu saat ini dapat diajukan hipotesa sebagai berikut:

Hipotesis 6: Semakin baik kapabilitas integrasi sumberdaya unggul anggota kolaborasi, maka semakin tinggi innovasi produk dan layanan perusabaan.

Kapabilitas integrasi sumberdaya yang adaptif akan berpengaruh terhadap reaksi beberapa pihak yang berinteraksi dengan perusahaan seperti mitra kolaborasi, konsumen dan pegawai, atas apa yang dilakukan dan dihasilkan perusahaan. Reaksi ini akan lebih baik ketika perusahaan memiliki kapabilitas untuk mengaplikasikan kemampuan dan ketrampilan yang dapat memandu terpenuhinya harapan para pihak. Perusahaan yang memiliki kapabilitas mengintegrasikan sumberdaya anggota kolaborasi akan mampu mengkoordinasikan dan mengkombinasikan sumberdaya dan para pihak terkait (stakebolders) (Teece et al., 1997) serta adaptif terhadap perubahan lingkungan.

Prieto dan Revilla (2006), menyatakan bahwa kapabilitas mampu meningkatkan kinerja non keuangan. Kapabilitas integrasi sumberdaya anggota kolaborasi diharapkan mampu meningkatkan kepuasan karyawan sehingga dapat menciptakan produk yang baik serta memberikan layanan yang memuaskan konsumen.

Sejalan dengan Arino (2003) bahwa intergasi sumberdaya anggota kolaborasi akan mampu mendorong efektifitas organisasi. Efektifitas organisasi dalam hal ini adalah tercapainya tujuan-tujuan organisasi. Kemampuan mengintegrasikan sumberdaya yang dikelola dalam kolaborasi mendorong tercapainya tujuan-tujuan organisasi, maka dapat diajukan hipotesis sebagai berikut:

Hipotesis 7: Semakin tinggi kapabilitas integrasi sumberdaya, maka semakin tinggi efektifitas kolaborasi.

Organisasi dengan inovasi yang besar akan memiliki keunggulan yang lebih baik sehingga mampu memenangkan 
persaingan pasar. Inovasi terkait dengan kemampuan organisasi dalam meningkatkan kinerja internal. Dengan demikian perusahaan yang memiliki inovasi yang tinggi cenderung akan lebih efektif dalam mencapai tujuan perusahaan (Burton, 1999). Inovasi mampu berkontribusi meningkatkan kemampuan untuk berinovasi lebih lanjut, pengembangan ketrampilan dan derajat responsitas terhadap perubahan pasar (Gold et al., 2001).

Menurut literatur tentang kapabilitas dinamis, rutinitas manajemen dan inovasi memungkinkan perusahaan untuk terusmenerus menghasilkan peningkatan efektivitas kinerja (Eisenhardt dan Martin, 2000 dan Collis, 1991). Lee dan Sukoco, 2007, menemukan bahwa derajat inovasi perusahaan secara positif mempengaruhi efektifitas perusahaan. Pengetahuan perusahaan tentang bagaimana memperbaharui sumber daya, dikembangkan dan diterapkan ke dalam rutinitas organisasi dan tertanam dalam model-model perilaku, sehingga memungkinkan perusahaan untuk mencapai keunggulan kompetitif (Teece et al., 1997). Strategi kolaborasi sebagai salah satu cara untuk mencapai suatu pembaharuan sumber daya dan merespon perubahan kondisi pasar, sehingga kapabilitas kolaborasi merupakan kapabilitas dinamis (Eisenhardt dan Martin, 2000). Perusahaan dengan kapabilitas kolaborasi yang kuat memiliki rutinitas organisasi yang memungkinkan untuk mengelola kolaborasi secara efisien dan efektif (Dyer \& Singh, 1998). Oleh karena itu dapat diajukan hipotesis sebagai berikut:

Hipotesis 8: Semakin tinggi derajat inovasi produk dan layanan yang dilakukan perusahaan, maka semakin tinggi pencapaian efektifitas organisasi.

Panayides (2006), menyatakan perusahaan lebih mudah mencapai peningkatan kinerja dengan cara menekankan pengembangan kapabilitas inovasi dan memiliki orientasi budaya organisasi yang mengarah kepada kapabilitas inovasi. Akamavi (2005) menyatakan bahwa inovasi produk keuangan memainkan peran yang penting dalam pengembangan keunggulan bersaing dan memberikan kontribusi pada kinerja keuangan perusahaan. Lembaga keuangan hendaknya memiliki portofolio produk keuangan yang seimbang 
untuk mempertahankan dan melindungi posisi pasarnya, kinerja keuangannya dan persaingan masa yang akan datang. Berdasarkan pemikiran Akamavi (2005) dan Panayides (2006) dapat ditarik simpul pemikiran bahwa inovasi produk dan layanan mampu mendorong peningkatan kinerja bisnis, sehingga dapat diajukan hipotesa sebagai berikut;

Hipotesis 9: Semakin tinggi derajat inovasi produk dan layanan, maka semakin baik kinerja bisnis perusabaan.

Keberhasilan efektifitas organisasi selanjutnya akan mendorong keberhasilan kinerja bisnis. Hal ini telah ditemukan oleh beberapa peneliti, seperti Tippins dan Sohi (2003) dan Calanton et al. (2002). Kapabilitas kolaborasi dinamis mampu memberikan kompetensi untuk melakukan efisiensi dan efektifitas pengembangan proses, produk dan layanan perusahaan. Hal ini mampu mengurangi biaya produksi, meningkatkan hasil, meningkatkan produktifitas dan meningkatkan pertumbuhan penjualan

Beberapa penelitian telah menemukan bahwa kepuasan konsumen, pangsa pasar dan profitabilitas terdapat hubungan yang kuat dan positif (Capon et al., 1990; Anderson et al., 1994). Kepuasan konsumen dapat menyebabkan konsumen menginginkan untuk kembali berinteraksi memanfaatkan produk dan jasa perusahaan di waktu yang akan datang. Dengan demikian, perusahaan yang secara konsisten mampu meningkatkan kualitas produk dan jasanya sehingga memuaskan konsumen diharapkan mampu meningkatkan kinerja keuangan perusahaan. Demikian juga dengan kepuasan karyawan yang kuat diharapkan berpengaruh terhadap hasil ekonomis perusahaan karena kepuasan karyawan mampu menghasilkan efisiensi dan produktifitas (Harter et al., 2002). Berdasarkan telaah di atas maka dapat diajukan hipotesis sebagai berikut:

Hipotesis 10: Semakin tinggi derajad efektifitas organisasi dalam berkolaborasi, maka semakin baik kinerja bisnis perusabaan.

Kapabilitas perusahaan dalam mengintegrasikan sumberdaya unggul kolaborasi mendorong perusahaan mampu memperoleh 
kinerja bisnis yang tinggi. Beberapa studi menemukan bahwa perusahaan yang secara konsisten memperoleh keuntungan lebih adalah perusahaan yang memiliki kapabilitas aliansi khusus (Anand dan Khanna, 2000 dan Kale et al., 2002). Keterampilan individual dalam menjalankan kolaborasi merupakan komponen dari kapabilitas organisasional yang melekat pada kegiatan operasional, Coriat (dikutip dari Heimeriks dan Duysters, 2006).

Heimeriks dan Duysters (2006) juga menemukan bahwa kapabilitas mengelola sumberdaya aliansi berpengaruh positif terhadap kinerja perusahaan. Kapabilitas yang dibangun dengan pengalaman dan pembelajaran mendukung kemampuan perusahaan dalam memanfaatkan sumberdaya baik yang telah dimiliki maupun hasil dari kolaborasi dengan perusahaan lain. Derajad kapabilitas mengelola sumberdaya kolaborasi ini menentukan berhasil tidaknya kinerja bisnis perusahaan.

Berdasarkan hasil penelitian Hyvonen dan Tuominen (2007) dan Heimeriks dan Duysters (2006) maka ditarik simpul pemikiran bahwa kapabilitas integrasi sumberdaya unggul anggota kolaborasi mampu mendorong peningkatan kinerja bisnis, sehingga dapat diajukan hipotesis sebagai berikut:

Hipotesis 11:Semakin tinggi kapabilitas integrasi sumberdaya, maka semakin tinggi kinerja bisnis perusahaan.

Dalam sebuah penelitian pada perusahaan eksportir, Bello dan Gilliland (1997) menemukan bahwa fleksibilitas organisasional perusahaan berpengaruh positif terhadap kinerja perusahaan. Sebagai bagian dari bentuk tatakelola hubungan bilateral, proses relasional antar perusahaan menuntut perilaku kolaboratif yang fleksibel dalam menyesuaikan diri diantara pihak yang berkolaborasi (Heide, 1994).

Lebih lanjut Antonio et al. (2008) menemukan bahwa fleksibilitas manajerial berpengaruh langsung meningkatkan kinerja keuangan perusahaan. Kesesuaian fleksibilitas manajerial dengan kondisi terkini mampu mendorong tercapainya peningkatan kinerja keuangan perusahaan. Demikian juga Gin dan Lee, et al. (2006) dalam penelitiannya menemukan bahwa fleksibilitas 
strategi perusahaan berpengaruh positif terhadap kinerja keuangan perusahaan. Fleksibilitas strategi sebagai manifestasi fleksibilitas sumberdaya, struktural dan relasional, berpengaruh langsung terhadap peningkatan kinerja keuangan perusahaan.

Berdasarkan hasil-hasil penelitian Bello dan Gilliland (1997), Antonio et al. (2008) dan Gin dan Lee (2006) dapat ditarik simpul pemikiran bahwa fleksibilitas organisasi mampu meningkatkan kinerja bisnis perusahaan, sehingga dapat diajukan hipotesis sebagai berikut:

Hipotesis 12: Semakin tinggi fleksibilitas organisasi, maka semakin tinggi kinerja bisnis perusabaan.

\section{Metode Penelitian}

Penelitian ini adalah basic research, dilakukan untuk memberikan kontribusi pada badan ilmu (contribution to the body of knowledge). Penelitian ini dimulai dari adanya research gap keberhasilan kolaborasi antar organisasi. Temuan penelitian ini diharapkan mampu memberikan kontribusi pada ilmu manajemen khususnya teori organisasi.

Unit analisis penelitian ini adalah Koperasi Simpan Pinjam Syariah (KJKS) dan Unit Jasa Keuangan Syariah (UJKS) di Jawa tengah. Populasi penelitian ini adalah manajer atau kepala cabang Koperasi Jasa Keuangan Syariah di Jawa Tengah sebanyak 639 unit pada tahun 2010 (Dinas Koperasi dan UMKN Jawa Tengah, 2011). Teknik pengambilan sampel dengan purposive sampling, digunakan sebanyak 151 koperasi syariah. Subjek penelitian ini adalah manajer koperasi simpan pinjam syariah yang tersebar di 12 kabupaten dan kota di Jawa Tengah.

Pengumpulan data menggunakan kuesioner dengan pertanyaan tertutup dan terbuka. Pengujian hipotesis menggunakan teknik two step approach. Teknik analisis penelitian ini memakai Structural Equation Model (SEM). 


\section{Analisis}

Berdasarkan telaah teori, pengembangan model dan hasil uji analisis maka dapat disajikan path diagram seperti dalam gambar 2. Nilai Chi-Square penelitian ini adalah 368,77 dengan signifikansi 0,08, lebih kecil dari chi-square tabel dengan degree of freedom 332 dan probabilitas 5\% sebesar 375,49, menunjukkan bahwa nilai Chi-Square tidak signifikan, berarti berdasarkan kriteria Chi-Square model fit.

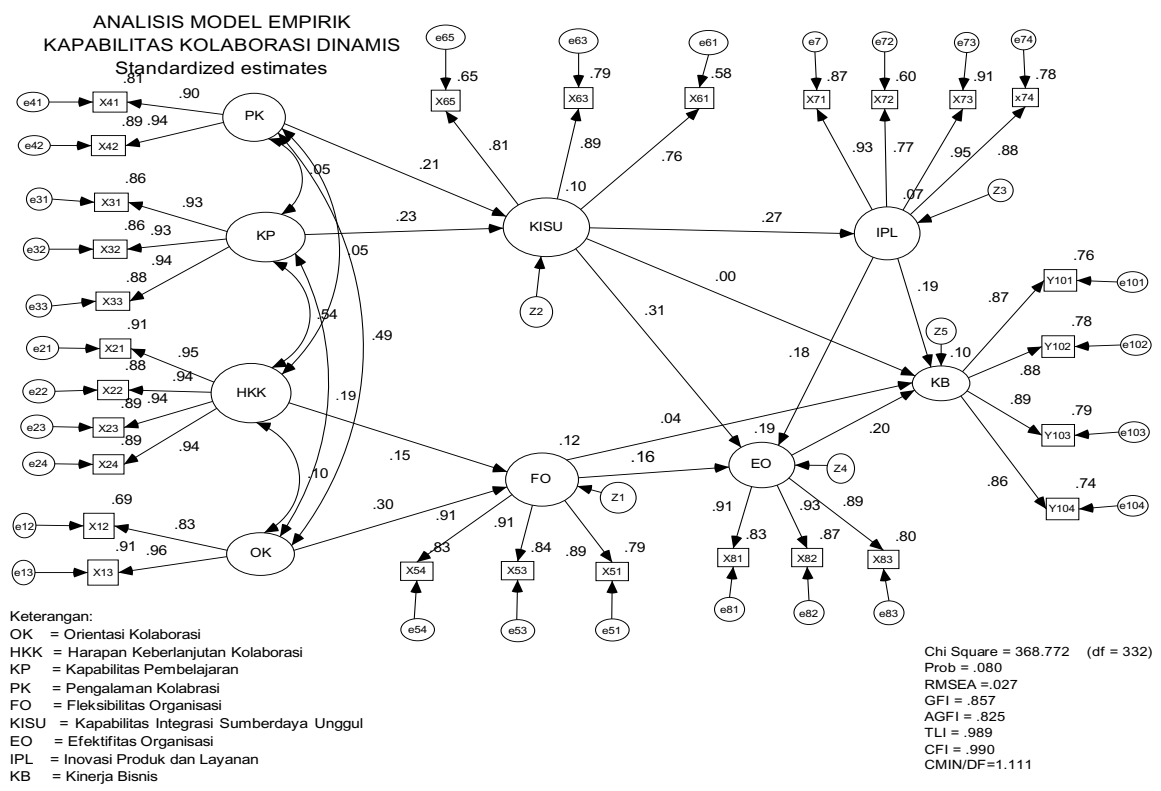

Sumber: Output Amos

Gambar 2

\section{Analisis Full Model Empirik Kapabilitas Kolaborasi Dinamis (Tahap III)}

Nilai GFI yang dihasilkan dalam penelitian ini adalah 0,86 nilai ini mendekati 1,0 meskipun masih lebih rendah dari 0,90, sehingga menurut GFI model ini kurang fit. Nilai AGFI yang dihasilkan dalam penelitian ini adalah 0,83 , nilai ini telah mendekati 1,0 meskipun lebih kecil dari 0,90, sehingga menurut AGFI model kurang fit. Nilai TLI yang dihasilkan dalam penelitian ini adalah 0,99 , nilai ini lebih besar dari 0,95 sehingga uji ketetapan model dikategorikan 
baik. Nilai CFI yang dihasilkan dalam penelitian ini adalah 0,99 lebih besar dari 0,95, sehingga uji ketepatan model dikategorikan baik. Nilai RMSEA dalam model penelitian ini sebesar 0,03 lebih kecil dari 0,08 sehingga uji ketepatan model dikategorikan baik.

Nilai CMIN/DF dalam penelitian ini adalah 1,11 lebih kecil dari 2, sehingga uji ketepatan model dikategorikan baik atau adequate fit/model. Dengan demikian berdasarkan kriteria goode ness of fit, menunjukkan analisis model dengan SEM pada model di atas dapat diterima sesuai model fit.

Tabel: 1

Standard Estimate - Regression Weights

\begin{tabular}{cccccccc}
\hline & & Std Est & Estimate & S.E. & C.R. & P & Label \\
\hline KISU <--- & KP & .229 & .231 & .087 & 2.654 & .008 & par_27 \\
KISU <--- & PK & .211 & .241 & .101 & 2.388 & .017 & par_28 \\
FO <--- & OK & .300 & .287 & .084 & 3.408 & $* * *$ & par_15 \\
FO <--- & HKK & .147 & .145 & .081 & 1.790 & .074 & par_16 \\
IPL <--- & KISU & .266 & .231 & .076 & 3.039 & .002 & par_35 \\
EO <--- KISU & .308 & .260 & .076 & 3.412 & $* * *$ & par_17 \\
EO <--- & IPL & .178 & .173 & .081 & 2.142 & .032 & par_24 \\
EO <--- & FO & .157 & .156 & .081 & 1.921 & .055 & par_26 \\
KB <--- & IPL & .187 & .178 & .085 & 2.104 & .035 & par_18 \\
KB <--- & EO & .198 & .193 & .093 & 2.084 & .037 & par_23 \\
KB <---- KISU & .000 & .000 & .082 & -.003 & .997 & par_36 \\
KB <--- & FO & .041 & .039 & .085 & .465 & .642 & par_37 \\
\hline \multicolumn{7}{c}{ Sumber: Output AMOS } \\
\end{tabular}

Hasil uji hipotesis disimpulkan bahwa dari 12 hipotesis terdapat 10 terbukti dan 2 hipotesis tidak terbukti yaitu hipotesis 11 dan 12. Hal ini dilakukan dengan menganalisa parameter estimasi, critical ratio (CR) dengan tingkat signifikansi 10\% masing-masing variabel independen, pengaruhnya terhadap variabel dependen.

Studi empiris yang dilakukan oleh Kandemir et al. (2006) menunjukkan bahwa orientasi aliansi mampu meningkatkan kapabilitas dalam mengelola krisis dan konflik dengan partner aliansi. Penelitian Kohli dan Jaworski (1990) dan Johnson et al. (2003) juga menemukan bahwa orientasi pada konsumen dan pesaing mampu meningkatkan kemampuan fleksibilitas dalam menciptakan nilai 
unggul bagi pelanggan. Dengan demikian orientasi pada relasi koĐ laborasi secara positif terhadap fleksibilitas manajerial perusahaan dalam mengelola kolaborasi sumberdaya unggul anggota kolaborasi.

Johnson (1999) menyatakan bahwa continuity expectation mendorong perusahaan semakin fleksibel dalam melakukan integrasi. Demikian juga Heide dan John (1990) menemukan bahwa continuity expectation meningkatkan derajaat joint action. Sehingga semakin besar harapan anggota kolaborasi untuk melakukan relasi kolaborasi secara berkelanjutan akan meningkatkan fleksibilitas manajerial perusahaan dalam mengelola kolaborasi sumberdaya unggul anggota kolaborasi.

Prieto dan Revilla (2006) yang mengemukakan bahwa kapabilitas pembelajaran mampu meningkatkan kemampuan mengkoordinasi dan mengkombinasi sumberdaya. Lin dan Kuo (2007) dan menemukan bahwa pembelajaran organisasional terbukti mampu meningkatkan kapabilitas manajerial dan integrasi sumberdaya. Richey dan Autry (2009) juga menyatakan bahwa organizational learning capability meningkatkan kualitas kolaborasi antar perusahaan (interfirm collaboration). Sehingga kapabilitas pembelajaran kolaborasi perusahaan berpengaruh positif terhadap kapabilitas integrasi sumberdaya unggul anggota kolaborasi, sehingga hipotesis 3 terbukti.

Heimeriks dan Duyster (2007), menemukan bahwa semakin banyak pengalaman maka semakin baik kapabilitas aliansi. Oliver SS. (2010) juga menemukan bahwa pengalaman aliansi masa lalu mampu meningkatkan kapabilitas aliansi perusahaan. Haleblian dan Finkelstein (1999) menemukan bahwa manajer dengan pengalaman yang luas maka kinerjanya lebih baik dibanding yang kurang berpengalaman, karena mampu mendapatkan dan mengelola sumberdaya secara lebih mudah. Oleh karena itu pengalaman dalam berkolaborasi mampu meningkatkan kapabilitas perusahaan dalam mengintegrasikan sumberdaya unggul anggota kolaborasi dan hipotesis 4 terbukti.

Bello dan Gilliland (1997:28) menemukan fleksibilitas yang dimiliki para pelaku kerjasama bilateral mampu meningkatkan efektifitas dan efisiensi kinerja kerjasama. Lebih lanjut Fawcett et al., (1996: 187) menemukan bahwa kompetensi flexibilitas memungkinkan 
perusahaan bisa melakukan sesuatu dengan cepat dan responsive terhadap pasar, sehingga flexibilitas berpengaruh positif terhadap kinerja. Ginn dan Lee (2006:118) menemukan bahwa fleksibilitas berpengaruh positif terhadap efektifitas perusahaan. Sehingga semakin tinggi fleksibilitas organisasi maka semakin baik efektifitas organisasi dalam kegiatan kolaborasi, dan hipotesis 5 terbukti.

Liao et al. (2009) yang menemukan bahwa kapabilitas integrasi mampu meningkatkan potensi inovasi dan mencipta produk dan jasa. Demikian juga hasil penelitian empirik Lok et al. (2008) menyebutkan bahwa kualitas kapabilitas integrasi mampu meningkatkan derajat inovasi perusahaan. Oleh karena itu maka dapat disimpulkan bahwa semakin baik kapabilitas integrasi suma berdaya unggul anggota kolaborasi, maka semakin tinggi inovasi produk dan layanan perusahaan.

Arino (2003) menemukan bahwa kapabilitas aliansi antar perusahaan mampu meningkatkan efektifitas organisasi. Kemampuan menginterasikan sumberdaya yang dikelola dalam kolaborasi mendorong tercapainya tujuan-tujuan oranisasi. Prieto dan Revilla (2006) juga menemukan bahwa kapabilitas integrasi mampu meningkatkan tercapainya tujuan-tujuan organisasi. Oleh karena maka semakin tinggi kapabilitas integrasi sumberdaya ungul, maka semakin tinggi efektifitas kolaborasi.

Lee dan Sukoco (2007) menemukan bahwa derajat inovasi perusahaan secara positif mempengaruhi efektifitas perusahaan. Gold et al. (2001) juga menemukan bahwa inovasi berkontribusi meningkatkan efektifitas organisasi. Berdasarkan hasil uji hipotesis 8 maka dapat disimpulkan bahwa semakin tinggi derajat inovasi produk dan layanan yang dilakukan perusahaan maka semakin tinggi pencapaian efektifitas organisasi.

Akamavi (2005) menyimpulkan bahwa inovasi mampu meningkatkan efisiensi, produktifitas dan kepuasan konsumen. Demikian juga Tsai (2010) menemukan bahwa semakin tinggi kapabilitas inovasi maka semakin tinggi kinerja bisnis. Panayides (2006) menyatakan bahwa semakin tinggi inovasi maka semakin tinggi kinerja. Oleh karena itu dapat disimpulkan bahwa semakin tinggi derajat inovasi produk dan layanan, semakin baik kinerja bisnis perusahaan. 
Parkhe (1993), mengemukakan bahwa efektifitas kinerja aliansi meningkatkan kinerja bisnis perusahaan. Capon et al. (1990) juga menemukan bahwa efektifitas pemanfaatan kapasitas organisasi mampu meningkatkan kinerja perusahaan. Anderson et al. (1994), menemukan bahwa efektifitas pencapaian kualitas layanan mampu meningkatkan kinerja perusahaan. Oleh karena hasil uji hipotesis 10 diterima maka dapat disimpulkan bahwa semakin tinggi efektifitas organisasi dalam berkolaborasi maka semakin baik kinerja bisnis perusahaan.

Hyvonen dan Tuominen (2007) dan Heimeriks dan Duysters (2007) menemukan bahwa kapabilitas mengintegrasikan sumberdaya dalam kegiatan kolaborasi antar perusahaaan berpengaruh positif terhadap kinerja keuangan. Derajad kapabilitas mengelola sumberdaya kolaborasi ini menentukan berhasil tidaknya kinerja bisnis perusahaan. Akan tetapi, Peterson dan Rajan (1994), Park dan Ungson (2001) dan Palakshapa dan Gordon (2007) menemukan integrasi sumberdaya dalam kolaborasi tidak berhasil meningkatkan kinerja. Hipotesis alternatif ditolak maka dapat disimpulkan bahwa kapabilitas integrasi sumberdaya unggul tidak berpengaruh positif terhadap kinerja bisnis.

Bello dan Gilliland (1997) dan Antonio et al. (2008) menemukan bahwa fleksibilitas organisasional dan fleksibilitas manajerial perusahaan berpengaruh positif terhadap kinerja perusahaan. Kesesuaian fleksibilitas manajerial dengan kondisi terkini mampu mendorong tercapainya peningkatan kinerja keuangan perusahaan. Berbeda dengan Gin dan Lee, et al. (2006) yang menemukan bahwa fleksibilitas strategi perusahaan berpengaruh positif terhadap kinerja keuangan perusahaan. Hipotesis alternatif ditolak maka dapat disimpulkan bahwa fleksibilitas organisasi tidak berpengaruh positif terhadap kinerja bisnis.

\section{Kesimpulan}

Berdasarkan hasil analisis model pengembangan kapabilitas kolaborasi dinamis di atas, maka dapat disimpulkan empat proses dasar untuk meningkatkan kinerja bisnis. Pertama, peningkatan kinerja bisnis lembaga keuangan syariah di Jawa Tengah dapat 
dibangun melalui proses orientasi dalam kolaborasi, fleksibilitas organisasi dan efektifitas organisasi, kedua, melalui proses haras pan keberlanjutan kolaborasi, fleksibilitas organisasi dan efektifitas organisasi, ketiga, melalui proses kapabilitas pembelajaran, kab pabilitas integrasi sumberdaya unggul dan efektifitas organisasi, keempat melalui proses pengalaman kolaborasi, kapabilitas integrasi sumberdaya unggul dan efektifitas organisasi.

Penelitian ini memiliki kelemahan beberapa kriteria Goodness offit yang kurang menunjukkan nilai yang disarankan oleh beberapa peneliti yaitu GFI dan square multiple correlation yang nilainya masih dibawah 0,5 . Oleh karena itu penelitian yang akan datang dapat modifikasi model yang lebih baik dan menambah determinan lain seperti kepercayaan (trust), komitmen dan altruisme.

\section{Daftar Pustaka}

Akamavi R.K., 2005, "Re-engineering service quality process mapping: e-banking process", The International Journal of Bank Marketing, pp. $28-53$

Anderson, J.G, 2005, Testing Model Fit, http://directory.umm.ac.id

Anderson, WA., Fornell, C., dan Lehmann, DF., 1994, "Customer satisfaction, market share, and profitability: Finding from Sweden", Journal of Marketing, Vol. 58, 3, 53-66

Ann V. dan Steve M., 2006, "Performance improvement through supply chain collaboration in Europe", International Journal of Operations E Production Management, Vol. 26, No. 11, pp. 1176-1198.

Antonio, J.V.J, Gomes-Grass, J.M. dan Montes, F.J.L, 2008, "Exploring managerial flexibility: determinants and performance implications", Industrial Management \& Data Systems, Vol. 108, No.1, 70-86.

Arino A., 2003, "Measures of strategic alliance performance: an analysis of construct validity", Journal of International Business Studies, 34, 66-79

Bello, D.C dan Gilliland D.I, 1997, "The Effect of Output Controls, Process Controls, and Flexibility on Export Channel Performance", Journal of Marketing, Vol. 61, 22-38.

Bolton, Patrick, and David S. Scharfstein, 1996, "Optimal debt structure and the number of creditors", Journal of Political Economy, 104, 1-25.

Burton, J., 1999, "Innovation, entrepreneurship and the firm: A post- 
Schumpeterian approach", International Journal of Technology Management, 17, 1-21

Capon, N., Farley, JU., dan Scott, 1990, "Determinants of Financial Performance: A Metta-Analysis", Management Science, 36, 10, 1143-1159

Carletti, E., Cerasi, V., dan Daltung, S., 2005, "Multiple-Bank Lending: Diversification and Free-Riding in Monitoring", Working-paper

Das, TK., dan Teng BS., 2000, "The dynamics of alliance conditions in the alliance development process", Journal of Management Studies, 39 (5): $725-746$

Diamond, D. W., 1984, "Financial Intermediation and Delegated Monitoring", Review of Economic Studies, LI, 393-414

Dimyati, A., 1989, Islam dan Koperasi: Telaah Peran Serta Umat Islam dalam Pengembangan Koperasi, Koperasi Jasa Informasi (KOPINFO), Jakarta.

Dyer, J.H. dan Singh, H., 1998, "The Relational view: Cooperative strategy and sources of interorganizational competitive advantage", Academy of Management Review, Vol.23 No.4, 660-679.

Eisenhardt, 1989, "Making fast strategic decisions in high-velocity environments", Academy of Management Journal 32 (3): 543-576.

Eisenhardt, K.M. dan Martin, J.A. (2000), "Dynamic capabilitites: What are they?", Strategic Management Journal, Vol. 21, p. 1105-1121

Erlena C., Cerasi V., dan Daltung S., 2005, "Multiple-bank Lending: diversification and free-riding in monitoring, Center for Financial Studies, University of Frankfrut", Working Paper No. 2004/18, p.1-27

Fawcett SE., Calantone R., dan Smith SR., 1996, "An Investigation of the impact of flexibility on global reach and firm performance", Journal of Business Logistics, Vol.17, No.2, 167-196

Ginn, G.O dan Lee, R.P., 2006, "Community Orientation, strategic flexibility and financial performance in hospitals", Journal of healthcare Management, 51, 2, 111-122.

Grant RM, 1996, "Toward a knowledge-based theory of the firm", Stategic Management Journal, Summer Special Issue 17: 109-122

Gulati, R., 1999, "Network location and learning: the influence of network resources and firm capabilities on alliance formation", Strategic Management Journal 20 (5): 397-420

Haleblian J., dan Frankenstein S., 1999, "The influence of organizational acquisition experience on acquisition performance: a behavioral 
learning perspective", Administrative Science Quarterly, Vol. 44 No.1, p. 29-56.

Hambrick, D. C., 1982, "Environmental scanning and organizational strategy", Strategic Management Journal, 3, 159-174.

Haris, M. dan Raviv, A., 1979, "Optimal Incentive Contracts With Imperfect Information", Journal of Economic Theory, 20, 231-259

Harter, J.K., Schmidt, F.L. dan Hayes, T.L., 2002, "Business unit level relationship between employee satisfaction, employee engagement and business outcomes, A Meta-analysis", Journal of Applied Psychology, 87, 268-279.

Heid B.J. dan John G., 1990, "Alliance in Industrial Purchasing: The determinants of joint action in buyer-supplier relationships", Journal of Marketing Research, Vol.27, 24-36

Heide, J.B., 1994, "Interorganizational governance in marketing channels", Journal of Marketing, Vol. 58, 71-85.

Heimeriks K.H. dan Duyslers G., 2007, "Alliance capability as a mediator between experience and alliance performance: An empirical investigation into the alliance capability development process", Journal of Management Studies, 44:1

Helfat CE, Raubitschek RS, 2000, "Product sequencing: co-evolution of knowledge, capabilities and products", Strategic Management Journal 21 (10-11): 961-979

Islahi, A.A, 1988, Economic Concepts of Ibn Taimiyah, The Islamic Foundation, 223 London Road, Leicester, UK.

Johnnson, J.L., Lee, R.P, Saini. A., dan Grohmann, 2003, "Market-focused strategic flexibility: Conceptual advances and an integrative model", Journal of the Academy of Marketing Science, Vol. 31, No.1, 74-89

Johnson et.al, 1999, "Strategis integration in industrial distribution channels: Managing the interfirm relationship as a strategic asset", Journal of Marketing Science, Vol, 27. No.1.

Judge WQ, Miller A, 1991, "Antecedents and outcomes of decision speed in different environtments", Academy of Management Journal 34(2): 449-464

Kale, P., Dyer, JH., dan Singh H., 2002, "Alliance capability, stock market respon, and long-term alliance success: The role of alliances function", Strategic Management Journal.

Kandemir, Destan, Yaprak A., dan Cavusgil ST., 2006, "Alliance orientation: conceptualization, measurement and impact on market performance", Journal of the Academy of Marketing Science, 34 


\section{(3), 324-340}

Ken Le M. F. dan Nigel F. P., 2007, "Does Collaboration Between Sales and Marketing Affect Business Performance?", Journal of Personal Selling \& Sales Management, Vol. XXVII, No.3, pp 207-220.

Kogut B, Zander U, 1992, Knowledge of the firm, combinative capabilities, and the replication of technology, Organization Science 3: 383-397

Kohli, Ajay K., dan Jaworski BJ., 1990, "Market orientation: The construct, research proporsitions, and managerial implication", Journal of Marketing, 54 (April), 1-18

Lee dan Sukoco BM., 2007, "The effect of entrepreneurial orientation and knowledge management capability on organizational effectiveness in Taiwan: The moderating role of social capital", International Journal of Management, Vol. 24, No.3, 549-620

Liao J., Kickul J.R dan Ma H., 2009, "Organizational dynamic capability and innovation: An Emirical examination of internet firms", Journal of Small Business Management, 47, 3.

Lin CY., dan Kuo TH., 2007, The mediate effect of learning and knowledge on organizational performance, Industrial Management and Data Systems, Vol. 107, No.7.

Lok, P., Rhodes, J., Hung, R., dan Fang, S.C., 2008, "An integrative model of organizational learning and social capital on effective knowledge transfer and perceived organizational performance", Journal of Workplace Learning, Vol. 20, No. 4, 245-258

Oliver S.S., 2010, Organizational routines as alliance capabilities: The missing lingk, Stanford University, 1-6

Palakshappa, N. dan Gordon, M.E., 2007, "Collaborative business relationships: Helping firms to acquire skills and economies to prosper", Journal of Small Business and Enterprise Development, Vol. 14 No.2, 264-279.

Panayides P., 2006, "Enhancing innovation capability through relationship management and implications for performance", European Journal of Innovation Management, Vol. 9.

Park, S.H dan Ungson, G.R., 2001, Interfirm rivalry and managerial complexity: A conceptual framework of alliance failure, Organiation Science, Vol. 12 No.1, 37-53

Parkhe,A., 1993, "Strategic alliance structuring: A Game theoretic and transaction cost examination of interfirm cooperation", Academy of Management Journal, 36, 4.

Petersen, M.A. dan Rajan, R.G., 1994, "Benefit from Lending Relationships: 
Evidence from Small Business Data", Journal of Finance, 49, 3-37 Prieto IM., dan Revila E., 2006, Learning capability and business performance: a non-financial and financial assesment, The Learning Organization, Vol. 13, No.2, 166-185

Richey dan Autry, 2009, "Assesing interfirm collaboration/technlogy investment trade off: The effect of technological readiness and orgaizational learning", International Journal of Logistic Management, Vol. 20, 1, 30-56.

Robin, S.P., 1994, Teori Organisasi, Struktur, Desain dan Aplikasi, Edisi 3, San Diego State University, Alih Bahasa Jusuf Udaya, Penerbit Arcan, Jakarta

Simonim B.L., 1997, "The importance of collaborative know-how: An empirical test of the learning organization", Academy of Management Journal. Briarcliff Manor: Oct 1997. Vol. 40, Iss. 5; pg. 1150, 25 pgs

Soetriono, 2004, Model Pengembangan Koperasi Yang Berorientasi Pada usaha yang Kuat, Infokop, Ed. 24.

Teece, D.J., Pisano G. Dan Shuen, A. (1997), "Dynamic capabilities and strategic management", Strategic Management journal, Vol. 17, Winter.

Tippins, M.J. dan Sohi, R.S., 2003, "Competency and firm performance: Is organizational learning a missing link?", Strategic Management Journal, 24, 745-761.

Tsai, M.T., 2010, "Innovation capability and performance in taiwanese science park: exploring the moderating effects of industrial clusters fabric", The International Journal of Organizational Innovation, Vol 2, 80-103

Van de Ven, A., 1976, "On the nature, formation and maintenance of relations among organizations", Academy of Management Review, 24-36.

Zineldin, M. dan Dodourova, M., 2005, "Motivation, achievements and failure of strategic alliances", European Business Review, Vol. 17 No. 5, 460-470. 